\title{
IN VITRO PROPAGATION OF F1 MALE HYBRID LINES IN ASPARAGUS OFFICINALIS
}

\author{
Amira R. Sallam \\ Tissue Culture Unit, Department of Genetic Resources, Desert Research \\ Center, El-Matareya, Cairo, Egypt \\ E-mail: amirarasheeddrc@gmail.com
}

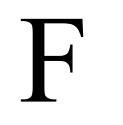

or mass production of super male hybrid lines of Asparagus officinalis (Mary Washington $500 \mathrm{~W}^{\prime} \mathrm{CV}$.), in vitro propagation system was initiated to obtain a sterile, healthy culture using shoot tip and single-node spear. Explants established on Murashige and Skoog (MS) medium supplemented with kinetin (KIN) at $1 \mathrm{mg} \mathrm{l}^{-1}$, naphthalene acetic acid (NAA) at $0.2 \mathrm{mg} \mathrm{l}^{-1}$ and gibberellic acid $\left(\mathrm{GA}_{3}\right)$ at $0.5 \mathrm{mg}^{-1}$ showed $100 \%$ of survival, the highest number of thick, dark green shoots (8.5) and nodes (8.7). Multiplication of shoots was carried out using benzyl amino purine (BAP) or KIN. BAP containing media gave higher shoot multiplication rate with high vitrification ratio in a positive correlation with concentration. The vitrification ratio was declined by replacing BAP with the same concentration of KIN $\left(2 \mathrm{mg} \mathrm{l}^{-1}\right)$. Adding the growth retardant; paclopatrazol (PP333) at $1.0 \mathrm{mg} \mathrm{l}^{-1}$ completely eliminated the vitrification. Direct somatic embryos from stem segment (internode) induced on MS medium supplemented with BAP at $1 \mathrm{mg}^{-1}$ and NAA at $0.1 \mathrm{mg} \mathrm{l}^{-1}$ and seedling regeneration occurred on MS medium with KIN at $1 \mathrm{mg} \mathrm{l}^{-1}$ and $\mathrm{GA}_{3}$ at $0.5 \mathrm{mg} \mathrm{l}^{-1}$. Medium supplemented with NAA, indole-3-butyric acid (IBA), PP333 and Aspergillus niger extract were tested for rooting. MS medium supplemented with IBA at $1.0 \mathrm{mg}^{-1}$ and PP333 at $0.5 \mathrm{mg} \mathrm{l}^{-1}$ was optimum for producing white-rooted plants (79.5\%) within 54 days from old clusters of shoots, which were better, compared to young single shoots. Healthy rooted clusters from each treatment were successfully transferred to growth champers then greenhouse for acclimatization.

Keywords: micropropagation, direct somatic embryo, vitrification, rooting, paclopatrazol, Aspergillus niger extract

Asparagus officinalis L. is belonging to Liliaceae family (Prohens et al., 2008). The most economically important Asparagus species is garden Asparagus (A. officinalis), which is a highly prized vegetable (Stajner et al., 2002 and Afroz and Abul Hassan, 2008), grown in temperate climate regions 
worldwide and widely cultivated, because of its edible spears of high economic, medicinal and food value. A. officinalis is native originated mainly from Asia, Africa and Europe (Prohens et al., 2008). It has been introduced and become naturalized in some parts of Europe, across Australasia and parts of North and South America (USDA, ARS, and National Genetic Resources Program, 2011). Asparagus is dioecious and highly heterozygous, traditionally propagated by seeds and the resulting seedlings contain equal proportions of male and female plants. Generally, male plants have more commercial advantages over the female plants. Male plants give much higher yields, are less susceptible to diseases than female plants and are longer lived. Female plants put much of their energy into producing copious quantities of seed (Lo' pez-Anido and Cointry, 2008 and Sarabi and Almasi, 2010). The female and super male parents cannot be propagated by seed, they can only be preserved by vegetative or asexual propagation (Chen, 2015). Male plants will never produce seeds, in order to obtain all-male hybrids; the production of super male is the key. Nevertheless, super male rarely exists in nature. Clonal propagation by division of the Asparagus crowns is possible, but the multiplication rate is low under optimal condition. In one year, only 2-4 new plants produce from one plant. When a superior male hybrid is identified, tissue culture is necessary, quick and a safe solution for large-scale production of the parents (Reuther, 1984).

In vitro propagation systems may be useful to develop virus eliminated and genetically stable plants. Expansively studies were carried out on several species of Asparagus that are considered as ornamental or medicinal plants such as A.s officinalis, through micropropagation, organogenesis and somatic embryogenesis (Stajner, 2013 and CarmonaMartin et al., 2014). A. officinalis is the first monocotyledonous species showed regeneration via somatic embryogenesis (Hisato and Masahiro, 1998). Direct somatic embryogenesis induced by tissue culture has a great potential for rapid and efficient clonal propagation. Somatic embryo involves the development of embryos from somatic cells and production of complete somatic plantlet. Somatic embryo maintains genetic stability in Asparagus and many studies focused on the production of direct somatic embryos (Levi and Sink, 1991; Conner and Abernethy, 1996 and Mustafa and Muhammad, 2017). Vitrification phenomenon (glassiness) or the malformation problem appears through multiplication stage, resulting in the occurrence of short and less chlorophyll stems in many kinds of plants (Phan and Hegedus, 1986). In vitrified plantlets, leaves have large vacuolated mesophyll cells, fewer stomata and less photosynthetic capacity. Their stem and leaves are often rigid, thick and breakable (Kevers et al., 2004 and Sharma and Mohan, 2006). Vitrified plants show difficulties in rooting and acclimatization and normal growing (Yadav et al., 2003 and Kevers et al., 2004). Growth retardants are able to modify the growth of plants when used

Egyptian J. Desert Res., 69, No. 1, 67-86 (2019) 
exogenously (Grossmann et al., 1985). Khunachak et al. (1987) used paclobutrazol $\left(\mathrm{PP}_{333}\right)$ as a growth retardant for improving Asparagus shoottips culture.

Several authors pointed out that major obstacle of Asparagus micropropagation protocols is not the establishment and multiplication of shoots, but root initiation. None of the existing pathways for large commercial scale propagation of Asparagus is useful, as regenerated plantlets have poor survival hardening rate (Desjardins, 1992). Asparagus plants require vigorously growing roots for successful transplantation, the obstacles of Asparagus rooting in vitro can be categorized into three aspects: 1 . low rooting rate, 2 . big mount of abnormal roots, 3 . low survival rate after transplanting to the greenhouse (Ren et al., 2012). From which shoots and roots are formed in vitro, two types of roots are formed: one is a white and vigorous root; the other is a transparent and less active root. The latter is easily formed but has no function as a root (Gonzalez, 2002; Lin et al., 2008 and Saharan, 2010). Also, auxin plays a key role in rooting, and exogenous auxins are required in many species. In many commercial propagation systems of other species, indole-3-butyric acid (IBA) is commercially used to induce roots on stem cuttings. IBA is most common used in Asparagus rooting in vitro (Chen, 2007; Behrooz and Kaveh, 2010 and Wang et al., 2010). Plant growth retardants are regarded as the most important group of plant growth regulators, their use in culture media significantly enhanced Asparagus in vitro culture and the field transplants (Rademacher, 2000). Incorporation of growth retardants can promote the growth of strong shoots and roots of Asparagus. Khunachak et al. (1987) investigated the effectiveness of some growth retardants including ancymidol, B-995, phosfon, Amo 1618, Cycocel (CCC) and $\mathrm{PP}_{333}$.

Using fungus extracts as a potential for rooting of in vitro propagated culture is well known (other classes of root symbionts have the same potential, as reviewed by Nowak (1998). Paulo et al. (2003) reached rooting induction with a combination of auxin and hypertonic shock in vitro. Aspergillus niger is one of the most common species of the genus Aspergillus. Aspergillus species are known to produce a variety of secondary metabolites in vivo or in vitro, that act as co-markers in the taxonomy of Aspergilla, biocontrol effectiveness, root induction (Siddiqui et al., 2004). Moreover, Aspergillus niger is one of the fungi labelled with the GRAS (generally recognized as safe) status from the US Food and Drug Administration (Powell et al., 1994). It was previously used as an elicitation to enhance the accumulation of secondary metabolites in in vitro culture of several plant species (Mendhulkar and Vakil, 2013). Thus, it would appear likely that certain combinations of Aspergillus niger and procedures of micropropagation could be exploited for the improvement of root development of $A$. officinalis in vitro. 
Not all types of explants are favorable for root stimulation. Fortes et al. (1997) studied the influence of young shoot number of Asparagus on rooting. It was reported that four-shoot explants rooted better than those with one, two or three shoots. Longer roots were also observed from the explant with four shoots. Wu et al. (2006) investigated the effect of plantlet age on the rooting rate. They found that plantlets older than four weeks $(8,12,16$ and 20 weeks) could have more rooting percentage $(>75 \%)$ after sub culturing for two weeks or more.

The objective of this investigation was to develop an efficient, and economic in vitro propagation protocol, for rapid and large-scale propagation of $A$. officinalis high productivity male hybrid, as recommended for commercial production, as well as overcoming the problems of in vitro propagation of Asparagus, especially vitrification and rooting.

\section{MATERIALS AND METHODS}

The experiments were carried out in the Plant Tissue Culture Unit, Department of Genetic Resources, Desert Research Center, Cairo, Egypt.

\section{Preparation of Plant Material}

A. officinalis (Mary Washington $500 \mathrm{~W}^{\prime} \mathrm{CV}$.) seeds were sown in an artificial medium (Peatmoss, vermiculite and sand) in $10 \mathrm{~cm}$ diameter pots (two seeds in each pot). After four weeks, plantlets were transferred to $20 \mathrm{~cm}$ diameter pots and one plantlet per pot.

Nodal segments of young spears, $8-10 \mathrm{~cm}$ long, from male hybrid line 10- to 12-week-old transplants, were taken as explants and washed carefully by soup solution and rinsed under tap water for about $40 \mathrm{~min}$. Surface sterilization was carried out by immersing them in $0.05 \mathrm{mg} \mathrm{l}^{-1}$ mercuric chloride $\left(\mathrm{HgCl}_{2}\right)$ solution for $10 \mathrm{~min}$. Then, explants were rinsed three times in double sterile distilled water. Murashige and Skoog (MS) medium (Murashige and Skoog, 1962) with vitamins supplemented with 100 $\mathrm{mg} \mathrm{l}^{-1}$ myo-inositol, $30 \mathrm{~g} \mathrm{l}^{-1}$ sources, $200 \mathrm{mg} \mathrm{l}^{-1}$ glutamine and $2.5 \mathrm{~g} \mathrm{ml}^{-1}$ phytagel was used in all experiments with different plant growth regulators (PGRs) according to each stge. The $\mathrm{pH}$ of medium was adjusted to 5.7-5.8 prior to autoclaving $\left(15 \mathrm{~min}\right.$ at $121^{\circ} \mathrm{C}$ and $1.5 \mathrm{~kg} \mathrm{~cm}^{-2}$ pressure). The cultures were incubated in a growth chamber at $25 \pm 2^{\circ} \mathrm{C}$ at a 16 -h photoperiod $(2500$ 3000 Lux) provided by cool-white fluorescent lamps.

\section{Establishment Stage}

Sterilized shoot tips and node segments were cut into $0.3-0.5 \mathrm{~cm}$ segments and cultured on MS medium supplemented with different concentrations of kinetin (KIN; 0.5, 1.0 and $1.5 \mathrm{mg} \mathrm{l}^{-1}$ ) in combination with $0.2 \mathrm{mg} \mathrm{l}^{-1}$ naphthalene acetic acid (NAA) and $0.5 \mathrm{mg} \mathrm{l}^{-1}$ gibberellic acid $\left(\mathrm{GA}_{3}\right)$, in addition to the MS medium without PGR as a control. Five 
explants in each jar and three jars were considered as one replicate, and four replicates were used for each treatment. Soot formation percentage, number of shoots per propagule, shoot length and number of nodes were measured after 30 days of culturing.

\section{Multiplication Stage}

Thick healthy initiated shoots (1-2 cm long with 2-3 nodes) were subcultured on MS medium supplemented with benzyl amino purine (BAP) or $\operatorname{KIN~}\left(1,2\right.$ and $\left.3 \mathrm{mg} \mathrm{l}^{-1}\right)$ in combination with $0.2 \mathrm{mg} \mathrm{l}^{-1} \mathrm{NAA}$ and $\mathrm{GA}_{3}$ at $0.5 \mathrm{mg} \mathrm{l}^{-1}$, in addition to MS medium without PGRs as a control. Explants were subcultured at least six times on the best multiplication medium every 30 days. Four explants in each jar and three jars were considered as one replicate, and four replicates were used for each treatment. Shoot formation percentage, number of shoots per propagule, and shoot length were measured.

\section{Overcoming Vitrification}

In order to overcome vitrification through multiplication stage BAP was exchanged by KIN $\left(1 \mathrm{mg} \mathrm{l}^{-1}\right)$. The effect of adding $\mathrm{PP}_{333}$ at $0.5,1.0,1.5$ and $2.0 \mathrm{mg} \mathrm{l}^{-1}$ was examined. Four culture tubes with one explant were considered as one replicate, and four replicates were used for each treatment. Survival percentage, normal explant percentage, shoot length and number of proliferated shoots were measured after 30 days of culturing.

\section{Induction of Direct Somatic Embryos}

Direct embryogenesis induction was examined from stem segment within 6-8 weeks on MS medium supplemented with BAP $(0.5,1.0,1.5$ and $2.0 \mathrm{mg} \mathrm{l}^{-1}$ ) and NAA at $0.1 \mathrm{mg} \mathrm{l}^{-1}$. Seedling regeneration was examined on MS media supplemented with $1 \mathrm{mg} \mathrm{l}^{-1} \mathrm{KIN}$ and $0.1 \mathrm{mg} \mathrm{l}^{-1} \mathrm{NAA}$. Six explants in each jar and three jars were considered as one replicate, three replicates were used in four treatments. Number of induced somatic embryos, germination percentage and shoots length were measured after 75 days of culturing.

\section{Rooting Stage}

Three experiments were conducted for inducing healthy whiterooted A. officinalis plantlets, using clusters of 5-8 shoots. MS free medium or supplemented with NAA $(0.5,1.0) \mathrm{mg}^{-1}$ and IBA $\left(0.5,1.0\right.$ and $1.5 \mathrm{mg} \mathrm{l}^{-}$ $\left.{ }^{1}\right)$ or IBA at $1.0 \mathrm{mg}^{-1}$ with $\mathrm{PP}_{333}\left(0.5\right.$ and $\left.1.0 \mathrm{mg}^{-1}\right)$. As well using Aspergillus niger fungus extract at 0, 50, 100, 150, 200, 250 and $500 \mathrm{mg} \mathrm{l}^{-1}$. Aspergillus niger fungus extract was prepared according to Taha et al. (2009). Type of explants (young single shoot or old cluster of shoots) effect was also evaluated for rooting. Four culture tubes and four baby jars with one cluster of shoots were considered as one replicate, and three replicates 
were used for each treatment. Time to induce roots, percentage of rooted explants, number of roots per plantlet and root length for white and transparent rooted explants were recorded after 20 weeks.

\section{Acclimatization Stage}

Healthy rooted clusters were transferred into $1: 1(\mathrm{v} / \mathrm{v})$ sand: peat sterilized mixture in jars in vitro for two weeks and then transferred into small pots $(10 \mathrm{~cm})$ in diameter, under in vivo conditions. The pots were covered with polyethylene bags for 2-3 weeks to maintain humidity. Then plantlets were transferred into large pots for 3-4 months.

\section{Experimental Design and Statistical Analysis}

This study was performed in completely randomized design. Mean comparisons were conducted with Duncan's multiple range test and the statistical analysis was analyzed with SPSS software. All the primary observation data were registered in Microsoft EXCEL software.

\section{RESULTS AND DISCUSSION}

Seedlings of F1 male hybrid lines 10- to 12-week-old of $A$. officinalis cv. Mary Washington 500 W', were efficiently regenerated in vitro, using MS medium with or without different PGRs through five experiments.

\section{Establishment Stage}

Shoot tip and node segment explants were established on MS control medium or supplemented with different concentrations $(0,0.5,1.0$ and 1.5 $\mathrm{mg} \mathrm{l}^{-1}$ ) of KIN combined with $0.2 \mathrm{mg}^{-1} \mathrm{NAA}$ and $0.5 \mathrm{mg} \mathrm{l}^{-1} \mathrm{GA}_{3}$. Results in table (1) indicate that no significant differences between treatments for the percentage of shoot formation were recorded and it reached $100 \%$ on MS medium supplemented with 0.5 and $1.0 \mathrm{mg} \mathrm{l}^{-1} \mathrm{KIN}$. The highest mean number of proliferated shoots/propagule (8.5) and number of nodes (8.7) were recorded at $1.0 \mathrm{mg} \mathrm{l}^{-1} \mathrm{KIN}$. However, the highest average shoot length $(11.15 \mathrm{~cm})$ was obtained from control treatment (MS medium without PGRs), followed by 0.5 and $1.0 \mathrm{mg} \mathrm{l}^{-1}$ of KIN, respectively with significant differences between them. In the present study, KIN showed a significant effect on almost all parameters, especially at $1.0 \mathrm{mg} \mathrm{l}^{-1}$. Ammirato (2004) reported that cytokinin at moderate concentrations enhances shoot development, as role for in vitro shoot propagation. Also, at low concentration of auxin (NAA) plus moderate concentration of cytokinin (KIN), good development of complete plantlets was shown from meristem tips of potato (Badoni and Chauhan, 2009). Similar results were also found by Guo et al. (1993), who reported that MS medium supplemented with KIN 
and NAA was more suitable for axillary and lateral buds from selected $A$. officinalis male plants in order to optimize proliferation ability.

Table (1). Effects of different levels of KIN on establishment stage of $A$. officinalis after 30 days of culturing on MS medium supplemented with $0.2 \mathrm{mg} \mathrm{l}^{-1} \mathrm{NAA}$ and $0.5 \mathrm{mg} \mathrm{l}^{-1} \mathrm{GA}_{3}$.

\begin{tabular}{cccccc}
$\begin{array}{c}\text { KIN level } \\
\left(\mathbf{m g ~ l}^{-1}\right)\end{array}$ & $\begin{array}{c}\text { Shoot } \\
\text { formation } \\
(\%)\end{array}$ & $\begin{array}{c}\text { No. of shoots/ } \\
\text { propagule }\end{array}$ & $\begin{array}{c}\text { Shoot } \\
\text { length } \\
(\mathbf{c m})\end{array}$ & $\begin{array}{c}\text { No. of } \\
\text { nodes/shoot }\end{array}$ & Notes \\
\hline 0.00 & $98.50^{\mathrm{a}}$ & $6.88^{\mathrm{b}}$ & $11.15^{\mathrm{a}}$ & $8.56^{\mathrm{a}}$ & $\begin{array}{c}\text { Thin, light green } \\
\text { explants }\end{array}$ \\
0.50 & $100.00^{\mathrm{a}}$ & $7.62^{\mathrm{ab}}$ & $9.58^{\mathrm{b}}$ & $7.96^{\mathrm{a}}$ & $\begin{array}{c}\text { Slightly thick, green } \\
\text { explants }\end{array}$ \\
1.00 & $100.00^{\mathrm{a}}$ & $8.50^{\mathrm{a}}$ & $8.85^{\mathrm{c}}$ & $8.70^{\mathrm{a}}$ & $\begin{array}{c}\text { Thick, dark green } \\
\text { explants }\end{array}$ \\
1.50 & $99.25^{\mathrm{a}}$ & $8.25^{\mathrm{a}}$ & $6.58^{\mathrm{b}}$ & $6.05^{\mathrm{b}}$ & $\begin{array}{c}\text { Thick, dark green } \\
\text { explants }\end{array}$ \\
\hline
\end{tabular}

Mean values followed by the same letter within a column are not significantly different. $P=0.05=$ Least significant difference test at 0.05 level of probability.

\section{Multiplication Stage}

Mass production of $A$. officinalis was induced in the multiplication stage by subculturing in vitro propagated healthy stem segment for six times at least. MS medium without PGR (control) in addition to that supplemented with BAP or KIN at 1,2 and $3 \mathrm{mg} \mathrm{l}^{-1}$ in combination with $0.2 \mathrm{mg} \mathrm{l}^{-1}$ NAA and $0.5 \mathrm{mg} \mathrm{l}^{-1} \mathrm{GA}_{3}$ were used. Data presented in table (2) illustrate that, shoot formation percentage reached $100 \%$ with each of $1.0,2.0$ and $3.0 \mathrm{mg} \mathrm{l}^{-}$ ${ }^{1} \mathrm{BAP}$ and 1.0 and $2.0 \mathrm{mg} \mathrm{l}^{-1} \mathrm{KIN}$. It was observed that, BAP containing medium gave the maximum values of shoot number (9.5), and shoot length $(12.13 \mathrm{~cm})$ at $2.0 \mathrm{mg} \mathrm{l}^{-1}$, but with high vitrification. On the other hand, KIN containing medium in the same concentration of $2.0 \mathrm{mg} \mathrm{l}^{-1}$ gave lower values (8.06 shoots and $8.62 \mathrm{~cm}$ length) but induced explants, which were normal, hard and green (Fig. 1). These results agree with Nemati et al. (2011), who focusing on the problem of vitrification in carnation (Dianthus caryophyllus L.), and reported that, there is a positive correlation between the concentration of cytokinin and vitrification, and adding BAP into the media resulted in more shoot multiplication and vitrification than KIN. 


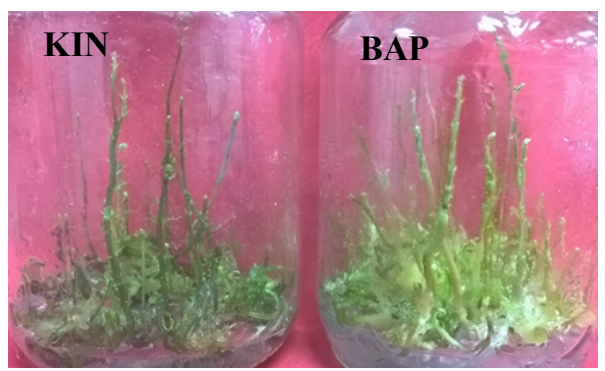

Fig (1). A composition between the effect of KIN and BAP at 2.0 $\mathrm{mg} \mathrm{1}^{-1}$ on A. officinalis in the multiplication stage.

Table (2). Effect of different levels of BAP and KIN on the multiplication stage of A. officinalis, on MS medium supplemented with $0.2 \mathrm{mg}$ $1^{-1} \mathrm{NAA}$ and $0.5 \mathrm{mg}^{-1} \mathrm{GA}_{3}$.

\begin{tabular}{|c|c|c|c|c|}
\hline Treatments & $\begin{array}{c}\text { Shoot formation } \\
(\%)\end{array}$ & $\begin{array}{l}\text { No. of shoots/ } \\
\text { propagule }\end{array}$ & $\begin{array}{c}\text { Shoots } \\
\text { length }(\mathrm{cm})\end{array}$ & Notes \\
\hline Control & $99.72^{\mathrm{a}}$ & $5.01^{\mathrm{d}}$ & $10.62^{\mathrm{b}}$ & Normal soft explants \\
\hline $1.0 \mathrm{mg} \mathrm{l}^{-1} \mathrm{BAP}$ & $100.00^{\mathrm{a}}$ & $7.07^{\mathrm{c}}$ & $11.40^{\mathrm{ab}}$ & $\begin{array}{l}\text { Soft explants with slight } \\
\text { vitrification }\end{array}$ \\
\hline $2.0 \mathrm{mg} \mathrm{l}^{-1} \mathrm{BAP}$ & $100.00^{\mathrm{a}}$ & $9.50^{\mathrm{a}}$ & $12.13^{\mathrm{a}}$ & $\begin{array}{l}\text { Soft, light green explants with } \\
\text { vitrification }\end{array}$ \\
\hline $3.0 \mathrm{mg} \mathrm{l}^{-1} \mathrm{BAP}$ & $100.00^{\mathrm{a}}$ & $8.15^{\mathrm{b}}$ & $10.58^{\mathrm{b}}$ & $\begin{array}{l}\text { Very soft, light green explants } \\
\text { with high vitrification }\end{array}$ \\
\hline $1.0 \mathrm{mg} \mathrm{l}^{-1} \mathrm{KIN}$ & $100.00^{\mathrm{a}}$ & $7.58^{\mathrm{bc}}$ & $8.45^{\mathrm{c}}$ & Normal, green explants \\
\hline $2.0 \mathrm{mg} \mathrm{l}^{-1} \mathrm{KIN}$ & $100.00^{\mathrm{a}}$ & $8.06^{\mathrm{b}}$ & $8.62^{\mathrm{c}}$ & Normal hard, green explants \\
\hline $3.0 \mathrm{mg} \mathrm{l}^{-1} \mathrm{KIN}$ & $96.75^{\mathrm{b}}$ & $7.50^{\mathrm{bc}}$ & $6.99^{\mathrm{d}}$ & $\begin{array}{l}\text { Hard, dark green explants } \\
\text { with slightly vitrification }\end{array}$ \\
\hline
\end{tabular}

\section{Vitrification}

Regarding vitrification or malformation problem, which appears during the multiplication stage, in the present study, BAP was replaced by KIN to overcoming vitrification. Results recorded in table (3) exhibit the effect of adding $\mathrm{PP}_{333}$ to the multiplication medium at $0.5,1.0,1.5$ and 2.0 $\mathrm{mg} 1^{-1}$. Concerning the survival percentage, it recorded $100 \%$ on MS 
(control) medium without PGRs and that supplemented with $0.5 \mathrm{mg}^{-1} \mathrm{PP}_{333}$, and then decreased in a negative correlation with $\mathrm{PP}_{333}$ levels, with significant differences. The normal explants percentage was increased significantly in a positive relationship with $\mathrm{PP}_{333}$ levels and gave the highest percentage of $100 \%$ at media containing 1.5 and $2.0 \mathrm{mg} \mathrm{l}^{-1} \mathrm{PP}_{333}$. Shoot length and number of proliferated shoots gave their highest mean values (10.75 cm and 7.81, respectively) at MS medium without PGRs (control) and the lowest mean values at $2.0 \mathrm{mg} \mathrm{l}^{-1} \mathrm{PP}_{333}$ in a significantly negative correlation. Although, from the obtained results, it can be noticed that, $\mathrm{PP}_{333}$ at $1.0 \mathrm{mg}^{-1}$ was the optimum concentration with moderate mean values of survival $(87.8 \%)$, normal explants percentage $(88 \%)$, shoot length $(7.62 \mathrm{~cm})$ and number of proliferated shoots (3.94), with normal thick, dark green explants (Fig. 2). These results are explained by Chin (1982), who referred that addition of growth retardants and gibberellin inhibitors improve shoot and root thickness and plantlets can survive when transferred to soil. Also, Khunachak et al. (1987) used $\mathrm{PP}_{333}$ as a growth retardant to improve $A$. officinalis shoot-tip culture. In the same trend, Guo et al. (1993) reported that the combinations of $\mathrm{PP}_{333}$, IBA, NAA and KIN on MS medium can be applied on axillary bud proliferation.

Table (3). Effect of different levels of $\mathrm{PP}_{333}$ on vitrification of A. officinalis shoots after 30 days of culturing on MS medium supplemented with KIN.

\begin{tabular}{|c|c|c|c|c|c|}
\hline $\begin{array}{l}\text { PP }_{333} \text { level } \\
\left(\mathrm{mg} \mathrm{l}^{-1}\right)\end{array}$ & $\begin{array}{l}\text { Survival } \\
(\%)\end{array}$ & $\begin{array}{c}\text { Normal } \\
\text { explants } \\
(\%)\end{array}$ & $\begin{array}{l}\text { Shoot } \\
\text { length } \\
\text { (cm) }\end{array}$ & $\begin{array}{c}\text { No. of } \\
\text { shoots/jar }\end{array}$ & Notes \\
\hline 0.0 & $100.00^{\mathrm{a}}$ & $46.75^{\mathrm{d}}$ & $10.75^{\mathrm{a}}$ & $7.81^{\mathrm{a}}$ & $\begin{array}{l}\text { Thin, Light green and } \\
\text { vitrified explant }\end{array}$ \\
\hline 0.5 & $100.00^{\mathrm{a}}$ & $73.31^{\mathrm{c}}$ & $8.31^{\mathrm{b}}$ & $6.15^{\mathrm{b}}$ & $\begin{array}{l}\text { Thin, hard, green and lower } \\
\text { vitrified explants }\end{array}$ \\
\hline 1.0 & $87.80^{\mathrm{b}}$ & $88.00^{\mathrm{b}}$ & $7.62^{\mathrm{b}}$ & $3.94^{\mathrm{c}}$ & $\begin{array}{l}\text { Normal thick, dark green } \\
\text { explants with root }\end{array}$ \\
\hline 1.5 & $80.89^{c}$ & $100.00^{\mathrm{a}}$ & $6.44^{\mathrm{c}}$ & $1.81^{\mathrm{d}}$ & $\begin{array}{l}\text { Thick, short and dark green } \\
\text { explants with root }\end{array}$ \\
\hline 2.0 & $62.75^{\mathrm{d}}$ & $100.00^{\mathrm{a}}$ & $3.02^{\mathrm{d}}$ & $1.31^{\mathrm{d}}$ & $\begin{array}{l}\text { Hard, very short and yellow } \\
\text { green explants with root }\end{array}$ \\
\hline
\end{tabular}

Mean values followed by the same letter within a column are not significantly different. $P=0.05=$ Least significant difference test at 0.05 level of probability. 


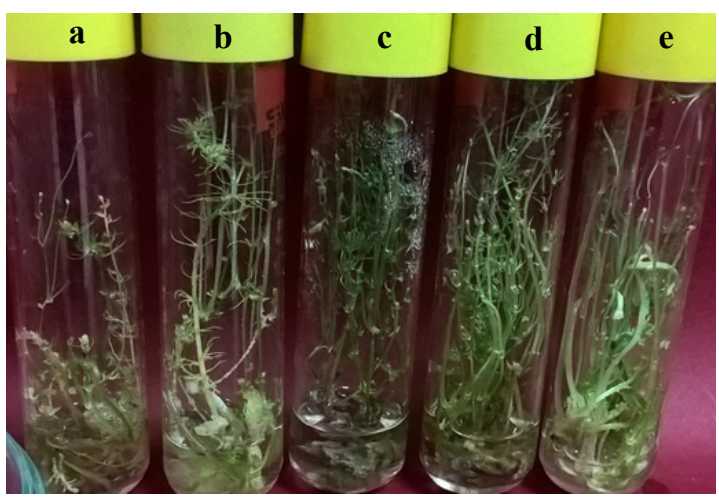

Fig. (2). Shoots of $A$. officinalis on MS medium supplemented with deferent levels of $\mathrm{PP}_{333}$, a. $2.0 \mathrm{mg}^{-1} \mathrm{PP}_{333}$, b. $1.5 \mathrm{mg} \mathrm{l}^{-1} \mathrm{PP}_{333}$, c. $1.0 \mathrm{mg} \mathrm{l}^{-1}$ $\mathrm{PP}_{333}$, d. $0.5 \mathrm{mg} \mathrm{l}^{-1} \mathrm{PP}_{333}$, and e. control treatment.

\section{Direct Somatic Embryogenesis}

Direct somatic embryogenesis involves the development of embryos from somatic cells and results in the production of complete plantlet with the potential to grow into a whole plant. Direct somatic embryos were induced from stem segment explants on MS medium without PGRs (control) or with BAP (0.5, 1.0, and $\left.2.0 \mathrm{mg} \mathrm{l}^{-1}\right)$. Data presented in table (4) and fig. (3) illustrate that, MS medium supplemented with $1.0 \mathrm{mg} \mathrm{l}^{-1}$ of BAP and NAA at $0.1 \mathrm{mg} \mathrm{l}^{-1}$ was the most suitable medium for inducing direct somatic embryogenesis in A. officinalis, which gave the highest mean number of induced somatic embryos (87 per jar) and percentage of germinated somatic embryos (93\%) with significant differences between other treatments (Fig. 4). Mean length of germinated shoots were increased significantly with BAP concentration in a positive correlation. The highest mean value was $5.56 \mathrm{~cm}$, recorded at $2.0 \mathrm{mg} \mathrm{l}^{-1}$. Similar results are investigated by Bojnauth et al. (2003), who induced somatic embryogenesis from nodal explants of $A$. officinalis on MS medium supplemented with $0.015 \mathrm{mg}^{-1}$ of NAA and BAP at $0.5 \mathrm{mg} \mathrm{l}^{-1}$, which gave the highest plantlet regeneration rate $(83.3 \%)$. Also, it was noticed that adding $0.5 \mathrm{mg} \mathrm{l}^{-1}$ of $\mathrm{PP}_{333}$ reduced vitrification during somatic induction and germination (Fig. 4). 
Table (4). Effects of different levels of BAP on direct induction and regeneration of somatic embryos from internodal explant on MS medium.

\begin{tabular}{ccccc}
$\begin{array}{c}\text { BAP level } \\
\left(\mathbf{m g ~ l}^{-1}\right)\end{array}$ & $\begin{array}{c}\text { No. of induced } \\
\text { somatic embryos }\end{array}$ & Germination (\%) & $\begin{array}{c}\text { Shoot length } \\
(\mathbf{c m})\end{array}$ & Notes \\
\hline 0.0 & 0.00 & 0.00 & 0.00 & $\begin{array}{c}\text { Shoots proliferation with } \\
\text { callus }\end{array}$ \\
0.5 & $63.00^{\mathrm{b}}$ & $84.46^{\mathrm{b}}$ & $4.56^{\mathrm{b}}$ & $\begin{array}{c}\text { Direct somatic embryos } \\
\text { inducing internodes } \\
\text { Direct somatic embryos } \\
\text { without vitrification }\end{array}$ \\
1.0 & $87.00^{\mathrm{a}}$ & $93.00^{\mathrm{a}}$ & $5.18^{\mathrm{ab}}$ & $\begin{array}{c}\text { Direct somatic embryos } \\
\text { with vitrification }\end{array}$ \\
2.0 & $49.00^{\mathrm{c}}$ & $65.90^{\mathrm{c}}$ & $5.56^{\mathrm{a}}$ & \multicolumn{4}{c}{$\begin{array}{c}\text { Mean values followed by the same letter within a column are not significantly } \\
\text { different. } P=0.05=\text { Least significant difference test at } 0.05 \text { level of probability. }\end{array}$}
\end{tabular}
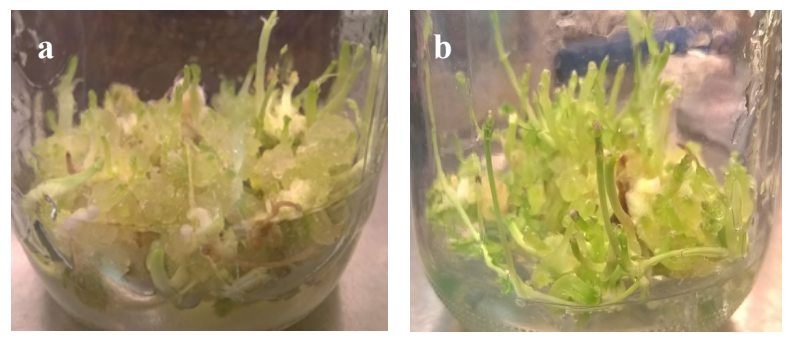

Fig. (3). a. direct somatic induction on MS medium supplemented with 1.0 mg $\mathrm{l}^{-1}$ BAP and NAA at $0.1 \mathrm{mg} \mathrm{l}^{-1}$. b. Somatic embryos germination on MS medium supplemented with $1.0 \mathrm{mg}^{-1} \mathrm{KIN}$ and NAA at $0.2 \mathrm{mg}^{-1}$
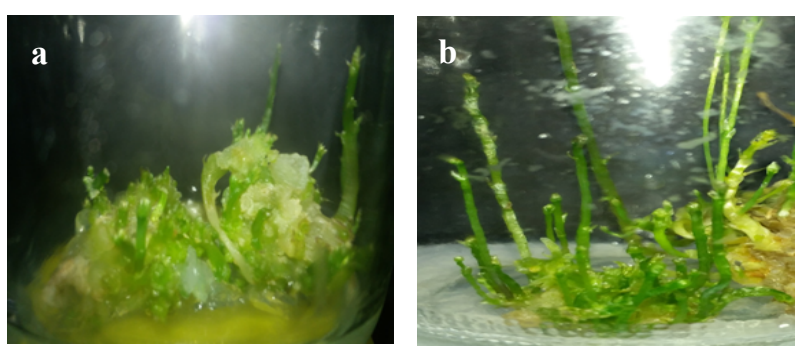

Fig. (4). a. Direct somatic induction on MS medium supplemented with 1.00 $\mathrm{mg} \mathrm{l}^{-1}$ BAP, NAA at $0.1 \mathrm{mg}^{-1}$ and $0.5 \mathrm{mg}^{-1}$.

b. Somatic embryos germination on MS medium supplemented with $1.00 \mathrm{mg} \mathrm{l}^{-1} \mathrm{KIN}, \mathrm{NAA}$ at $0.2 \mathrm{mg} \mathrm{l}^{-1}$ and $0.5 \mathrm{mg} \mathrm{l}^{-1}$. 


\section{Rooting Stage}

For successful transplantation of $A$. officinalis in vitro produced plantlets, it is required to improve vigorous storage roots (white-root). In vitro A. officinalis plantlets with few, weak, thin fibrous roots (transparent root) may be a big problem, they not only have poor survival rates, but the growth of the plants that do establish in soil is very slow (Gonzalez, 2002). There are many factors affecting $A$. officinalis rooting. Only with the healthy explant materials, proper culture medium and growth conditions can $A$. officinalis plantlets be produced and later successfully grown in the greenhouse (Ren et al., 2012). Transparent and white-rooted plantlets of $A$. officinalis were induced in vitro, using MS medium without PGRs (control) or that supplemented with NAA $\left(0.5\right.$ and $\left.1.0 \mathrm{mg} \mathrm{l}^{-1}\right)$, IBA $(0.5,1.0$ and 1.5 $\mathrm{mg} \mathrm{l}^{-1}$ ) individually or also IBA at $1.0 \mathrm{mg} \mathrm{l}^{-1}$ with the growth retardant $\mathrm{PP}_{333}$ $\left(0.5\right.$ and $\left.1.0 \mathrm{mg} \mathrm{l}^{-1}\right)$. It is noticeable that the transparent roots were formed first and then followed by white roots. Data presented in table (5) show that, the transparent roots were formed at all treatments at different times. The rooted explants percentage reached $100 \%$ at $1.0 \mathrm{mg} \mathrm{l}^{-1}$ IBA and $0.5 \mathrm{mg} \mathrm{l}^{-1}$ and $1.0 \mathrm{mg} \mathrm{l}^{-1} \mathrm{PP}_{333}$, and the highest mean root per plantlet (9.69) also was recorded at $1.0 \mathrm{mg} \mathrm{l}^{-1} \mathrm{IBA}$ and $0.5 \mathrm{mg} \mathrm{l}^{-1} \mathrm{PP}_{333}$, but root length was the highest $(13.50 \mathrm{~cm})$ at MS control medium.

Table (5). Effect of different PGRs levels (NAA, IBA and $\mathrm{PP}_{333}$ ) on rooting stage of $A$. officinalis on MS medium.

\begin{tabular}{|c|c|c|c|c|c|c|c|}
\hline \multirow[b]{2}{*}{ Treatments } & \multirow{2}{*}{$\begin{array}{l}\text { Time to } \\
\text { induce } \\
\text { roots } \\
\text { (days) }\end{array}$} & \multicolumn{3}{|c|}{ White rooted plantlets } & \multicolumn{3}{|c|}{ Transparent rooted plantlets } \\
\hline & & $\begin{array}{c}\text { Rooted } \\
\text { explants } \\
(\%) \\
\end{array}$ & $\begin{array}{c}\text { No. of } \\
\text { roots/ } \\
\text { plantlet }\end{array}$ & $\begin{array}{l}\text { Root } \\
\text { length } \\
\text { (cm) }\end{array}$ & $\begin{array}{c}\text { Rooted } \\
\text { explants } \\
(\%)\end{array}$ & $\begin{array}{l}\text { No. of } \\
\text { roots/ } \\
\text { plantlet }\end{array}$ & $\begin{array}{l}\text { Root } \\
\text { length } \\
(\mathrm{cm})\end{array}$ \\
\hline Control & $143.75^{\mathrm{e}}$ & 0.00 & 0.00 & 0.00 & $70.16^{\mathrm{cd}}$ & $5.25^{\mathrm{c}}$ & $13.50^{\mathrm{f}}$ \\
\hline $0.5 \mathrm{mg} \mathrm{l}^{-1} \mathrm{NAA}$ & $98.75^{\mathrm{d}}$ & 0.00 & 0.00 & 0.00 & $49.83^{\mathrm{f}}$ & $1.53^{\mathrm{d}}$ & $10.42^{\mathrm{e}}$ \\
\hline $1.0 \mathrm{mg} \mathrm{l}^{-1} \mathrm{NAA}$ & $98.00^{\mathrm{d}}$ & 0.00 & 0.00 & 0.00 & $54.70^{\text {ef }}$ & $1.90^{\mathrm{d}}$ & $10.53^{\mathrm{e}}$ \\
\hline $0.5 \mathrm{mg} \mathrm{l}^{-1} \mathrm{IBA}$ & $72.50^{\mathrm{c}}$ & $20.3^{\mathrm{d}}$ & $1.46^{\mathrm{d}}$ & $0.83^{\mathrm{d}}$ & $65.10^{\mathrm{de}}$ & $5.75^{\mathrm{c}}$ & $8.98^{\mathrm{de}}$ \\
\hline $1.0 \mathrm{mg} \mathrm{l}^{-1} \mathrm{IBA}$ & $65.00^{c}$ & $40.50^{\mathrm{c}}$ & $2.52^{\mathrm{c}}$ & $2.13^{\mathrm{bc}}$ & $78.10^{\mathrm{bc}}$ & $4.81^{\mathrm{c}}$ & $8.24^{\mathrm{cd}}$ \\
\hline $1.5 \mathrm{mg} \mathrm{l}^{-1} \mathrm{IBA}$ & $62.50^{\mathrm{bc}}$ & $51.25^{\mathrm{b}}$ & $4.25^{\mathrm{b}}$ & $2.81^{\mathrm{b}}$ & $86.93^{\mathrm{b}}$ & $4.85^{\mathrm{c}}$ & $7.15^{\mathrm{bc}}$ \\
\hline $\begin{array}{l}1.0 \mathrm{mg} \mathrm{l}^{-1} \mathrm{IBA}+ \\
0.5 \mathrm{mg} \mathrm{l}^{-1} \mathrm{PP}_{333}\end{array}$ & $53.75^{\mathrm{ab}}$ & $79.50^{\mathrm{a}}$ & $5.45^{\mathrm{a}}$ & $3.96^{\mathrm{a}}$ & $100^{\mathrm{a}}$ & $9.69^{\mathrm{a}}$ & $6.28^{\mathrm{ab}}$ \\
\hline $\begin{array}{l}1.0 \mathrm{mg} \mathrm{l}^{-1} \mathrm{IBA}^{+} \\
1.0 \mathrm{mg} \mathrm{l}^{-1} \mathrm{PP}_{333}\end{array}$ & $43.75^{\mathrm{a}}$ & $74.88^{\mathrm{a}}$ & $2.65^{\mathrm{c}}$ & $1.94^{\mathrm{c}}$ & $100^{\mathrm{a}}$ & $7.88^{\mathrm{b}}$ & $4.84^{\mathrm{a}}$ \\
\hline
\end{tabular}

Mean values followed by the same letter within a column are not significantly different. $P=0.05=$ Least significant difference test at 0.05 level of probability 
The time for inducing roots (transparent or white) was decreased significantly by using various PGRs. The longest time period (143.75 days) for inducing roots was MS control medium, and the shortest time period (43.75 days) was $1.0 \mathrm{mg} \mathrm{l}^{-1}$ IBA and $1.0 \mathrm{mg} \mathrm{l}^{-1} \mathrm{PP}_{333}$. Concerning the effect of the different concentrations of PGRs induced white-rooted plantlets, it was noticed that, the percentage of white-rooted plantlets, number of white rootsplantlet, and white root length were increased significantly by increasing IBA concentration. While, the highest mean values were $79.50 \%$, 5.45 and $3.96 \mathrm{~cm}$, respectively were recorded with $1 \mathrm{mg} \mathrm{l}^{-1}$ IBA and $0.5 \mathrm{mg}$ $1^{-1} \mathrm{PP}_{333}$ (Fig. 5). Control MS medium and NAA concentrations didn't record any significant values.

A. officinalis micropropagation often resulted in weak plants with spindly roots and shoots, which were difficult to establish in the soil. It observed that addition of $\mathrm{PP}_{333}$ as a growth retardant with IBA was effective in inducing white-rooted plantlets and improved shoot and root morphological characters. The similar observation was recorded by Chin (1982), who referred that addition of growth retardants, gibberellin inhibitors, improve shoot and root thickness, and therefore the plantlets can survive when transferred to soil. In the same way, also Ren et al. (2012), reported considerable improvement of shoot development in A. officinalis with ancymidol, but $\mathrm{PP}_{333}$ gave slightly higher rooting rate than ancymidol. $\mathrm{Wu}$ et al. (2006) showed that the growth retardant $\mathrm{PP}_{333}\left(1 \mathrm{mg} \mathrm{l}^{-1}\right)$ mixed with BAP as well as KIN were the appropriate medium for rooting culture pretreatment. Also, Alsalihy et al. (2004) found that $1.5 \mathrm{mg} \mathrm{l}^{-1}$ of IBA gives the highest number of roots and the longest roots and IBA $\left(0.75 \mathrm{mg} \mathrm{l}^{-1}\right)$ with PP $333\left(0.06\right.$ and $\left.0.12 \mathrm{mg} \mathrm{l}^{-1}\right)$ were the optimal for the rooting of peach rootstock. On the other hand, Górecka et al. (1998) found that the highest rooting rate $(30 \%)$ was observed from $A$. officinalis plantlets cultured on the medium with ancymidol. Where, Behrooz and Kaveh (2010) reported that IBA at $1.5 \mathrm{mg} \mathrm{l}^{-1}$ gives higher rooting percentage (43\%) of A. officinalis. Wang et al. (2010) showed that $A$. officinalis rooting ability had the greatest sensitivity to NAA at $0.2 \mathrm{mg} \mathrm{l}^{-1}$, through which $35.5 \%$ rooting rate was obtained. On the contrary, $0.5 \mathrm{mg} \mathrm{l}^{-1}$ IBA was more beneficial to the growth of roots.

An experiment was conducted to study the effect of Aspergillus niger extract concentration $\left(50,100,150,200\right.$, and $\left.250 \mathrm{mg} \mathrm{l}^{-1}\right)$ on white-root induction. Table (6) illustrates that, the highest values of the mean white-root percentage of $32.50 \%$ and highest mean white-root number of plantlets (3.00) were recorded at $200 \mathrm{mg} \mathrm{l}^{-1}$ of $A$. niger extract. It had no significant effect on inducing white-root explants after 80 days compared to PGRs (IBA and $\mathrm{PP}_{333}$ ) (Fig. 6). Taha et al. (2009) studied the effect of Aspergillus niger as biotic stress on Catharanthus roseus callus growth parameters. The best results of callus growth parameters were observed with $0.15 \%$ and the highest value of total alkaloids resulted in $0.25 \%$ of Aspergillus niger. 
Also, it was observed that, old cluster of shoots were better compared to young single shoots. Using old cluster of shoots reduced the induction of roots for all treatments. These results are confirmed by Shen et al. (1995), who found that when both a cluster of shoots (with 2-5 shoots) and a single shoot were used as explants, higher rooting percentage $(78.9 \%)$ was observed from shoot clusters, compared to single shoot tips, which only gave $25.7 \%$ rooting. On the other hand, Gebler (2005) stated that none of the single shoots of $A$. officinalis could develop storage roots. Conner et al. (1990) described that the ideal type for micropropagated A. officinalis plantlets should consist of an in vitro minicrown with 4-6 shoots, $1-2 \mathrm{~cm}$ long and 3-4 storage roots, $4-5 \mathrm{~cm}$ long.

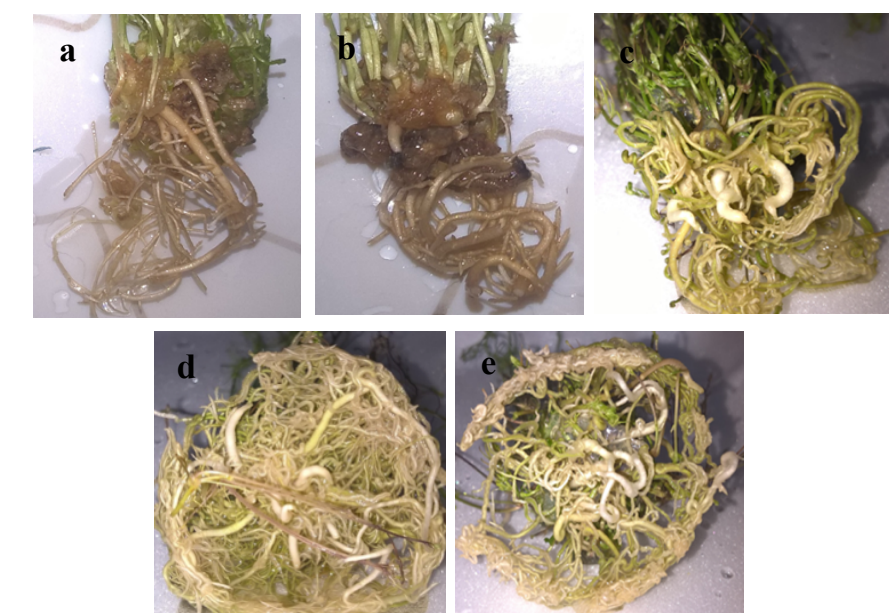

Fig. (5). Rooting of $A$. officinalis on MS medium supplemented with a. IBA at $0.5 \mathrm{mg} \mathrm{l}^{-1}$, b. IBA at $1.0 \mathrm{mg} \mathrm{l}^{-1}$, c. IBA at $1.5 \mathrm{mg} \mathrm{l}^{-1}$, d. IBA at 1.0 $\mathrm{mg} \mathrm{l}^{-1}+\mathrm{PP}_{333}$ at $0.5 \mathrm{mg} \mathrm{l}^{-1}$ and e. IBA at $1.0 \mathrm{mg} \mathrm{l}^{-1}+\mathrm{PP}_{333}$ at $1.0 \mathrm{mg}$ $1^{-1}$.

Table (6). Effects of different concentration of Aspergillus niger extract on in vitro rooting of $A$. officinalis after 80 days.

\begin{tabular}{ccccc}
\hline $\begin{array}{c}\text { A. niger extract level } \\
\left(\mathbf{m g ~ l}^{\mathbf{1}}\right)\end{array}$ & \multicolumn{2}{c}{ White rooted explants } & \multicolumn{2}{c}{ Transparent rooted explants } \\
\cline { 2 - 5 } & $\begin{array}{c}\text { Rooted explants } \\
\mathbf{( \% )}\end{array}$ & $\begin{array}{c}\text { No. of roots/ } \\
\text { plantlet }\end{array}$ & $\begin{array}{c}\text { Rooted explants } \\
\mathbf{( \% )}\end{array}$ & $\begin{array}{c}\text { No. of roots/ } \\
\text { plantlet }\end{array}$ \\
\hline Control & 0.00 & 0.00 & $30.00^{\mathrm{c}}$ & $9.67^{\mathrm{a}}$ \\
50 & $12.50^{\mathrm{c}}$ & $1.00^{\mathrm{bc}}$ & $40.00^{\mathrm{bc}}$ & $8.50^{\mathrm{ab}}$ \\
100 & $16.25^{\mathrm{c}}$ & $2.00^{\mathrm{ab}}$ & $45.00^{\mathrm{bc}}$ & $10.50^{\mathrm{a}}$ \\
150 & $20.00^{\mathrm{bc}}$ & $1.50^{\mathrm{b}}$ & $56.25^{\mathrm{ab}}$ & $5.00^{\mathrm{b}}$ \\
200 & $32.50^{\mathrm{a}}$ & $3.00^{\mathrm{a}}$ & $65.00^{\mathrm{ab}}$ & $4.50^{\mathrm{b}}$ \\
250 & $27.50^{\mathrm{ab}}$ & $1.75^{\mathrm{b}}$ & $72.50^{\mathrm{a}}$ & $7.25^{\mathrm{ab}}$ \\
\hline
\end{tabular}

Mean values followed by the same letter within a column are not significantly different. $P=0.05=$ Least significant difference test at 0.05 level of probability. 


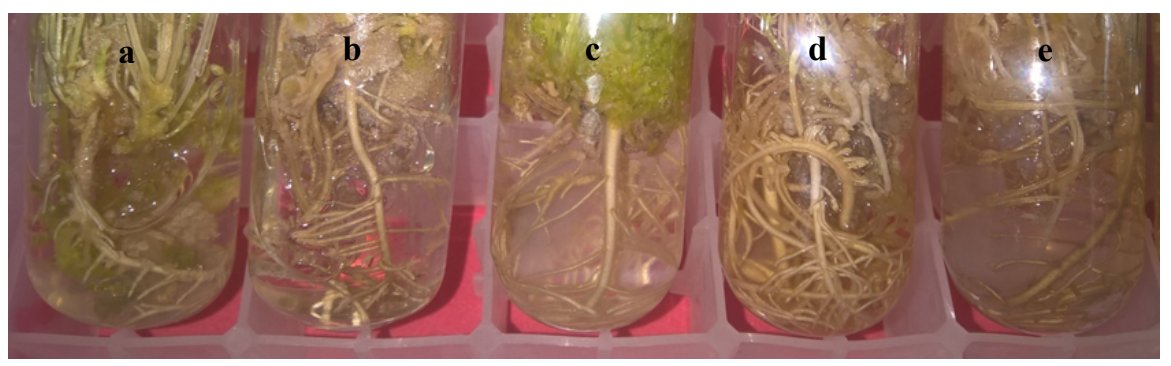

Fig. (6). Rooting of $A$. officinalis using different concentrations of Aspergillus niger extract, a. $50 \mathrm{mg} \mathrm{l}^{-1}$, b. $100 \mathrm{mg} \mathrm{l}^{-1}$, c. $150 \mathrm{mg} \mathrm{l}^{-1}$, d. $200 \mathrm{mg} \mathrm{l}^{-1}$ and e. $250 \mathrm{mg} \mathrm{l}^{-1}$.

\section{Acclimatization stage}

Healthy rooted clusters were successfully transferred to a sterilized mixture of $1: 1 \mathrm{v} / \mathrm{v}$ sand: peat for three weeks in a growth chamber, then gradually acclimatized in the greenhouse with a percentage of survival of about $34 \%$ after four months.
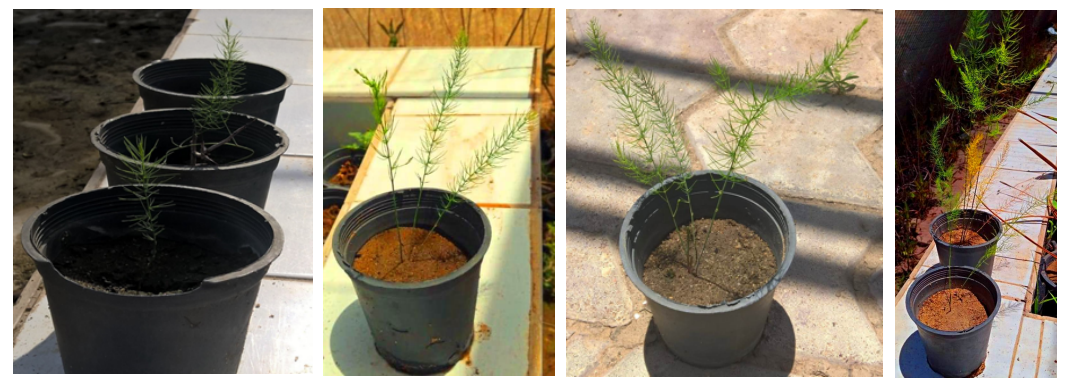

Fig. (7). A. officinalis in the acclimatization stage under greenhouse conditions.

\section{CONCLUSION}

In order to develop an efficient and economic in vitro propagation protocol, for rapid and large-scale propagation of $A$. officinalis male hybrid, from nodal explants, MS medium supplemented with KIN at $1 \mathrm{mg} \mathrm{l}^{-1}$, NAA at $0.2 \mathrm{mg} \mathrm{l}^{-1}$ and $\mathrm{GA}_{3}$ at $0.5 \mathrm{mg} \mathrm{l}^{-1}$ for the establishment stage and MS medium supplemented with $2 \mathrm{mg} \mathrm{l}^{-1} \mathrm{KIN}$ and $0.2 \mathrm{mg} \mathrm{l}^{-1} \mathrm{NAA}$ for the multiplication were the best treatments. For overcoming the problems of vitrification, adding the growth retardant $\mathrm{PP}_{333}$ at $1.0 \mathrm{mg} \mathrm{l^{-1 }}$ to the multiplication medium eliminated the vitrification definitely. Also, MS medium supplemented with BAP at $1 \mathrm{mg} \mathrm{l}^{-1}$ and NAA at $0.1 \mathrm{mg} \mathrm{l}^{-1}$ was the suitable treatment for direct somatic embryogenesis. For in vitro rooting, 
IBA at $1.0 \mathrm{mg} \mathrm{l}^{-1}$ and $\mathrm{PP}_{333}$ at $0.5 \mathrm{mg} \mathrm{l}^{-1}$ was the optimum treatment for producing white-rooted plants $(79.50 \%)$. Acclimatization was successful when transplants were transferred into greenhouse with a percentage of survival of about $34 \%$.

\section{ACKNOWLEDGMENT}

I am eternally grateful to my dear Professor Dr. Ghada A. Hegazi, Professor of Plant Biotechnology, who is supporting me in this work and all time to success.

\section{REFERENCES}

Alsalihy, A., B. Křižan, M. Klemš, H. Fišerová and J. Hradilík (2004). The effect of growth regulators on the rooting of shoots of the peach rootstock Ishtara in in vitro conditions. Horticultural Science, 31. 10.17221/3805-HORTSCI.

Ammirato, P.V. (2004). Yams. In: "Handbook of Plant Cell Culture". Ammirato, P.V., D.A. Evans, W.R. Sharp and Y. Yamada (Eds.). Macmillan, New York, 3: 329-354.

Badoni, A. and J.S. Chauhan (2009). A note on micro tuber seed production of potato: necessitate step for uttarakhand hills. Report and Opinion, $1(5): 9-11$.

Behrooz, S. and A. Kaveh (2010). Indirect organogenesis is useful for propagation of Iranian edible wild asparagus (Asparagus officinalis L.). Asian Journal of Agricultural Sciences, 2 (2): 47-50.

Bojnauth, G., S. Puchooa and T. Bahorun (2003). In vitro regeneration of Asparagus officinalis: preliminary results. Food and Agriculture Research Council, Reduit, Mauritius, AMAS, 7-15.

Carmona-Martin, E., J.J. Regalado, I.M.G. Padilla, N. Westendorp and C.L. Encina (2014). A new and efficient micropropagation method and its breeding applications in Asparagus genera. Plant Cell, Tissue and Organ Culture, 119 (3): 479-488.

Chen, Z.D. (2007). Studies of technology systems for tissue culture and rapid propagation of Asparagus offcinallis L. Southwest China J. Agric. Sci., 20 (3): 470-473.

Chen, X. (2015). Development of a liquid micropropagation system for Asparagus officinalis L. M.Sc. Thesis, The University of Guelph, Guelph, Ontario, Canada.

Chin, C.K. (1982). Promotion of shoot and root formation in asparagus in vitro by ancymidol (growth retardant, tissue culture). HortScience, 17: 590-591.

Egyptian J. Desert Res., 69, No. 1, 67-86 (2019) 
Conner, A.J. and D.J. Abernethy (1996). Genetic engineering of asparagus: assessment of methods, field testing and safety considerations, Acta Hort., 415: 51-58.

Conner, A.J., D.J. Abernethy and P.G. Falloon (1990). Transplantation of micropropagated asparagus plants to greenhouse conditions: the importance of in vitro root development. Acta Hort., 271: 128.

Desjardins, Y. (1992). Micropropagation of Asparagus (Asparagus officinalis L.). In: "High-Tech and Micropropagation". Bajaj, Y., (Ed.). Biotechnology in Agriculture and Forestry. Berlin Heidelberg, Springer-Verlag, 19: 26-41.

Fortes, G., N. Muller, E. Augustin, J. Silva, J. Peters and R. Flores (1997). The influence of spear number on in vitro rooting of asparagus (Asparagus officinalis L.). HortScience, 32 (3): 471.

Gebler, P. (2005). Method development of obtaining supermale asparagus (Asparagus officinalis L.). Ph.D. Thesis, Pozna University of Life Sciences, Poland, p. 1-84.

Gonzalez, C.M.L. (2002). Asparagus anther culture. Influence of genotype and growth environment conditions of the donor plants on the androgenetic response. Acta Hort., 589: 211-215.

Górecka, K., D. Krzyanowska and R. Górecki (1998). The effect of different factors on asparagus rooting in vitro and adaptation. Materialy konferencji i obrad sekcji 51 Zjazdu PTB, Gdask,167 p.

Grossmann, K., E. Weiler and J. Jung (1985). Effects of different sterols on the inhibition of cell culture growth caused by the growth retardant tetcyclacis. Planta, 164: 370-375.

Guo, C.H., F.T. Ma, Q.R. Zhang and M.X. Li (1993). Root induction of asparagus in vitro by $\mathrm{PP}_{333}$. J. Northwest Sci-Tech Univ. Agric. Forestry, 21 (3): 32-36.

Hisato, K. and M. Masahiro (1998). Somatic embryogenesis and its application for breeding and micropropagation in Asparagus (Asparagus officinalis L.). Plant Biotechnology, 15 (2): 51-61.

Ren, J., W. Chen and M. Knaflewski (2012). Factors affecting Asparagus (Asparagus officinalis L.) root development in vitro. Acta Sci. Pol., Hortorum Cultus, 11 (6): 107-118.

Kevers, C., T. Frank, R.J. Strasser, J. Dommes and T. Gaspar (2004). Hyperhydricity of micropropagated shoots: a typically stress induced change of physiological state. Plant Cell Tissue Organ Cult., 77: 181-191.

Khunachak, A., C.K. Chin, T. Le and T. Gianfagna (1987). Promotion of asparagus shoot and root growth by growth retardants. Plant Cell Tissue Organ Cult., 11: 97-110.

Levi, A. and C. Sink (1991). Histology and morphology of Asparagus somatic embryos. HortScience, 26 (10): 1322-1324. 
Lin, Z.K., Z.D. Chen, K.X. Cai, J.J. Yang and T.X. Zhang (2008). A study on the effects of several plant growth regulators on rooting of white asparagus (Asparagus officinalis L.) test-tube seedling from anther culture. Acta Agriculturae Univ. Jiangxiensis, 30 (4): 651-655.

Lo' pez-Anido, F. and E. Cointry (2008). Asparagus. In: "Vegetables II". DOI: 10.1007/978-0-387-74110-9_3.

Nemati, M.K.H., A. Tehranifar, A. Bagheri and A. Sharifi (2011). In vitro culture of carnation (Dianthus caryophyllus L.) focusing on the problem of vitrification. J. Biol. Environ. Sci., 5 (13): 1-6.

Mendhulkar, V.D. and M.M.A. Vakil (2013). Chitosan and Aspergillus niger mediated elicitation of total flavonoids in suspension culture of Andrographis paniculata (Burm. F.) Nees. D. Int. J. Pharm. Bio. Sci., 4 (4): (B) $731-740$.

Murashige, T. and F. Skoog (1962). A revised medium for rapid growth and bio assays with tobacco tissue cultures. Physiologia Plantarum, 15 (3): 473-497.

Mustafa, A.A. and N.A. Muhammad (2017). Regeneration of Asparagus officinalis L. through embryogenic callus. Plant Tissue Cult. Biotech., 27 (1): 21-31.

Nowak, J. (1998). Benefits of in vitro "biotization" of plant tissue cultures with microbial inoculants. In vitro Cell. Dev. Biol.-Plant, 34: 122130.

Paulo, O., J. Barriga, C. Cavaleiro, A. Peixe and Z. Potes (2003). Sustained in vitro root development obtained in Pinus pinea L. inoculated with ectomycorrhizal fungi. Forestry, 76: 579.

Phan, C.T. and P. Hegedus (1986). Possible metabolic basis for the development of anomaly observed in in vitro culture, called 'vitreous plants'. Plant Cell, Tissue and Organ Culture, 6: 83-94.

Powell, K.A., A. Renwick and J.F. Peberdy (1994). The genus Aspergillus, from taxonomy and genetics to industrial application. Plenum Press, New York.

Prohens, J., F. Nuez and M.J. Carena (2008). In: "Handbook of Plant Breeding”. Springer Publishing, $364 \mathrm{p}$.

Rademacher, W. (2000). Growth retardants: effects on gibberellin biosynthesis and other metabolic pathways. Annu. Rev. Plant Biol., 51: 501-531.

Reuther, G. (1984). Asparagus. In: "Handbook of Plant Cell Culture", Vol. 2, Edited by Sharp. Evans, W.R., D.A. Amminato and Y. Yamada (Eds.). New York: Macmillan Publishing Co., p. 211- 242.

Saharan, V. (2010). Effect of gibberellic acid combined with saponin on shoot elongation of Asparagus officinalis. Biologia Plant., 54 (4): $740-742$.

Egyptian J. Desert Res., 69, No. 1, 67-86 (2019) 
Sarabi, B. and K. Almasi (2010). Indirect organogenesis is useful for propagation of Iranian edible wild asparagus (Asparagus offcinalis L.). Asian Journal of Agricultural Sciences, 2 (2): 47-50.

Sharma, U. and J.S.S. Mohan (2006). Reduction of vitrification in in vitro raised shoots of Chlorophytum borilivinum Sant. and Fernand., a rare potent medicinal herb. Indian J. Exp. Biol., 44: 499-505.

Shen, S., D. Zou, C. Zhang and S. Liu (1995). Improved rate of callus and plantlet from anther culture of asparagus (Asparagus officinalis L). Acta Hort., 402: 299-305.

Siddiqui, I.A. S.S. Shaukat and A. Khan (2004). Differential impact of some Aspergillus species on Meloidogyne javanica biocontrol by Pseudomonas fluorescens strain. Letters in Applied Microbiology, 39: 74-83.

Stajner, N. (2013). Micropropagation of Asparagus by In Vitro Shoot Culture. In: "Protocols for Micropropagation of Selected Economically-Important Horticultural Plants". New York: Humana Press., p. 341-351.

Stajner, N., B. Bohanec and J.M. Arijana (2002). In vitro propagation of Asparagus maritimus - a rare Mediterranean salt-resistant species. Plant Cell Tiss. Org., 70: 269-274.

Afroz, S. and M. Abul Hassan (2008). Systematic studies in the family Liliaceae from Bangladesh. Bangladesh J. Plant Taxon., 15 (2): 115128.

Taha, A.Y., E. Filo, D.W. Ma and B.W. McIntyre (2009). Dose-dependent anticon-vulsant effects of linoleic and alpha-linolenic polyunsaturated fatty acids on pentylenetetrazol induced seizures in rats. Epilepsia, 50: 72-82.

Wang J.Y., X.P. Zhang, R. Yang, X.F. Li (2010). Effects of auxins on the propagation of Asparagus officinalis L. J. East China Normal Univ. (Nature Science), 6: 101-108.

Wu, C.R., L.N. Liu, A.P. Yu, X.M. Zhao and G.Y. Zhou (2006). Different factors on formation of rooting in Asparagus officinalis in vitro. Bull. Botanic. Res., 26 (4): 430-434.

Yadav, M.K., A.K. Gaur and G.K. Garg (2003). Development of suitable protocol to overcome hyperhydricity in carnation during micropropagation. Plant Cell, Tissue and Organ Culture, 72: 153156. 


\title{
الإكثار المعملي للجيل الأول للاجين المذكر في الأسبرجس
}

\author{
أميرة رشيد سلام \\ قسم الأصول الور اثية، مركز بحوث الصحر اء، المطرية، القاهرة، مصر
}

من أجل إنشاء نظام فعال لإكثار الجيل الأول للهجين الدذكر في الأسبرجس معطيًا

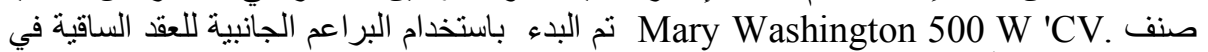

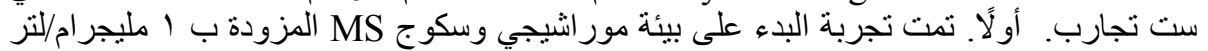

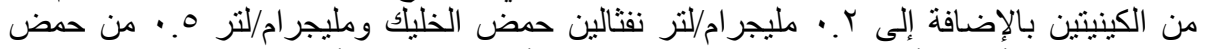

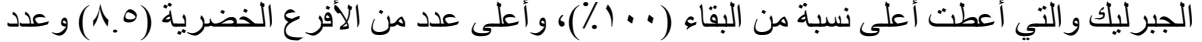

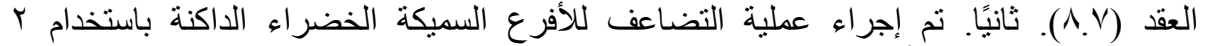

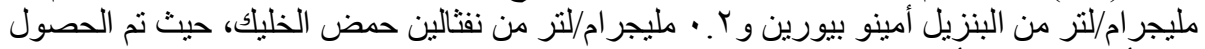

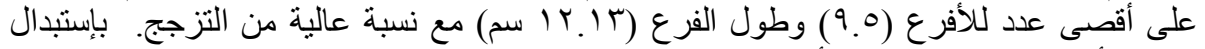

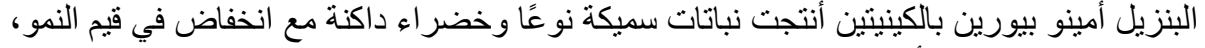

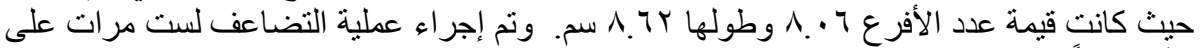

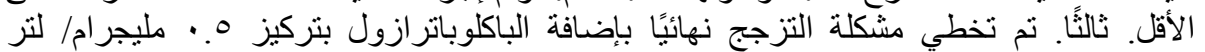

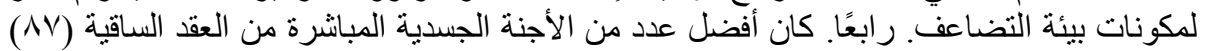

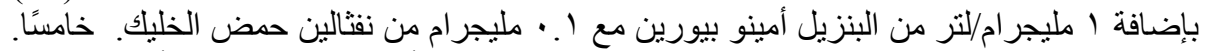

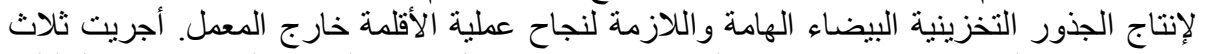

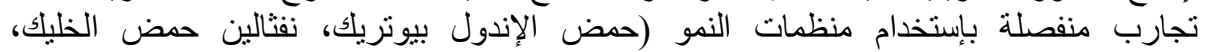

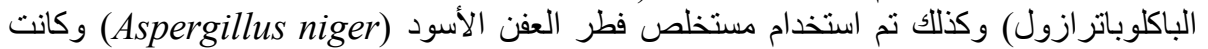

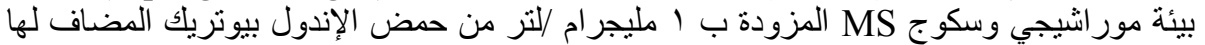

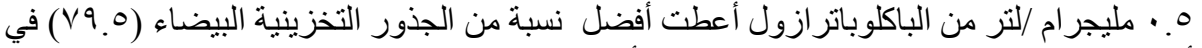

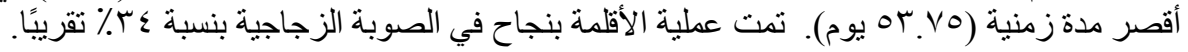

Egyptian J. Desert Res., 69, No. 1, 67-86 (2019) 